\title{
Article \\ Effect of Confining Conditions on the Hydraulic Conductivity Behavior of Fiber-Reinforced Lime Blended Semiarid Soil
}

\author{
Abdullah Ali Shaker ${ }^{1} \mathbb{D}$, Mosleh Ali Al-Shamrani ${ }^{1, *}$, Arif Ali Baig Moghal ${ }^{2, * \mathbb{D}}$ and Kopparthi Venkata Vydehi ${ }^{2} \mathbb{D}$ \\ 1 Bugshan Research Chair in Expansive Soils, Department of Civil Engineering, College of Engineering, \\ King Saud University, P.O. Box 800, Riyadh 11421, Saudi Arabia; shaker83@windowslive.com \\ 2 Department of Civil Engineering, National Institute of Technology, Warangal 506004, India; \\ kvvydehi252@gmail.com \\ * Correspondence: shamrani@ksu.edu.sa (M.A.A.-S.); baig@nitw.ac.in (A.A.B.M.)
}

check for updates

Citation: Shaker, A.A.; Al-Shamrani, M.A.; Moghal, A.A.B.; Vydehi, K.V. Effect of Confining Conditions on the Hydraulic Conductivity Behavior of Fiber-Reinforced Lime Blended Semiarid Soil. Materials 2021, 14, 3120 . https://doi.org/10.3390/ma14113120

Academic Editors:

Krzysztof Schabowicz and

Zbyšek Pavlík

Received: 21 April 2021

Accepted: 2 June 2021

Published: 6 June 2021

Publisher's Note: MDPI stays neutral with regard to jurisdictional claims in published maps and institutional affiliations.

Copyright: (c) 2021 by the authors. Licensee MDPI, Basel, Switzerland. This article is an open access article distributed under the terms and conditions of the Creative Commons Attribution (CC BY) license (https:/ / creativecommons.org/licenses/by/ $4.0 /)$.

\begin{abstract}
The hydraulic properties of expansive soils are affected due to the formation of visible cracks in the dry state. Chemical stabilization coupled with fiber reinforcement is often considered an effective strategy to improve the geotechnical performance of such soils. In this study, hydraulic conductivity tests have been conducted on expansive clay using two different types of fibers (fiber cast (FC) and fiber mesh (FM)) exhibiting different surface morphological properties. The fiber parameters include their dosage (added at $0.2 \%$ to $0.6 \%$ by dry weight of soil) and length ( 6 and $12 \mathrm{~mm}$ ). Commercially available lime is added to ensure proper bonding between clay particles and fiber materials, and its dosage was fixed at $6 \%$ (by dry weight of the soil). Saturated hydraulic conductivity tests were conducted relying on a flexible wall permeameter on lime-treated fiberblended soil specimens cured for 7 and 28 days. The confining pressures were varied from 50 to $400 \mathrm{kPa}$, and the saturated hydraulic conductivity values $\left(\mathrm{k}_{\mathrm{sat}}\right)$ were determined. For FC fibers, an increase in fiber dosage caused $\mathrm{k}_{\text {sat }}$ values to increase by $9.5 \%$ and $94.3 \%$ for the 6 and $12 \mathrm{~mm}$ lengths, respectively, at all confining pressures and curing periods. For FM fibers, $\mathrm{k}_{\text {sat }}$ values for samples mixed with $6 \mathrm{~mm}$ fiber increased by 12 and $99.2 \%$ for 6 and $12 \mathrm{~mm}$ lengths, respectively for all confining pressures at the end of the 28-day curing period. The results obtained from a flexible wall permeameter (FWP) were compared with those of a rigid wall permeameter (RWP) available in the literature, and the fundamental mechanism responsible for such variations is explained.
\end{abstract}

Keywords: confining pressure; expansive clay; fiber; flexible wall permeameter; hydraulic conductivity; lime; rigid wall permeameter

\section{Introduction}

Desiccation heave and shrinkage characteristics of expansive soils have limited their application as a subbase for roadway pavements material in arid and semiarid climates. Randomly oriented fibers are often used to reduce the problems associated with clayey soils. The cost-effectiveness and chemical inertness of the fibers makes them useful as a soil additive [1,2]. To develop the bonding between soil grains, researchers used chemical stabilizers such as lime, cement, EICP, MICP, biopolymer, etc., in combination with fiber to improve the geotechnical properties [3-6]. The addition of fiber to the soil increases shear strength [7], reduces swelling [8,9], reduces desiccation cracking [10], and increases hydraulic conductivity $(\mathrm{k})$ values [11,12]. Although fiber inclusion reduces the desiccation cracking, an increase in $\mathrm{k}$ values of soil limited its application in the subbase for the construction of pavements. However, the resultant properties of fiber-reinforced soil depend on the fiber type, dosage, and aspect ratio [13]. Experimental investigations on medium plasticity clay with polypropylene fiber (at $2 \%$ ) inclusion results in an increase in $\mathrm{k}$ values by $10^{-3} \mathrm{~cm} / \mathrm{s}$ compared to untreated clay. The fiber dosage up to $0.5 \%$ resulted in acceptable hydraulic conductivity values [12]. On the contrary, k values of lime-amended high-plastic clay reduced by $10^{-2} \mathrm{~cm} / \mathrm{s}$ with a fiber dosage of $0.2 \%$ and length of $6 \mathrm{~mm}$ at the end of 
28-day curing period compared to specimens without curing [14]. To meet the requirements of hydraulic conductivity values for lime-stabilized high-plastic clay reinforced with fiber, an optimum length of $10.5 \mathrm{~mm}$ with $0.5 \%$ dosage for a 15 -day curing period is proposed using the response surface method [15]. On the other hand, few researchers have studied the effect of lime on the hydraulic conductivity of soils. The results showed an increase in the hydraulic conductivity with lime [16-18]. In addition, the $\mathrm{k}$ value of lime-treated soil increased at initial curing periods and then decreased at higher curing periods [19,20]. Earlier research concentrated on evaluating the hydraulic conductivity of fiber-reinforced soil using a conventional rigid wall permeameter (RWP).

However, for a compacted clay as a subgrade layer, the surcharge load coming on it plays a major role in controlling the hydraulic conductivity values. According to Daniel et al. [21], complete control over imposed stress on the soil is not possible, resulting in the inability of RWP to measure vertical and horizontal deformations. To overcome these limitations, a flexible wall permeameter (FWP) was introduced, in which back pressure saturation and the minimization of sidewall leakages facilitate in determining the accurate value of saturated hydraulic conductivity values $\left(\mathrm{k}_{\text {sat }}\right)$ [22]. Therefore, to simulate the real field conditions, researchers proposed using FWP to evaluate $\mathrm{k}_{\text {sat }}$ values. Experimental investigations on sand-Alqatif clay mixture revealed that $\mathrm{k}_{\text {sat }}$ values reduced with an increase in confining pressure [23]. The generalized mechanism proposed for the reduction of $k_{\text {sat }}$ values using FWP is that an increase in confining pressure reduces the effective pore spaces, and an increase in unit weight leads to a reduction of effective flow paths.

There are limited studies on the evaluation of $\mathrm{k}_{\text {sat }}$ values for fiber-reinforced soil using FWP. In lieu of this, the present research evaluates the $k_{\text {sat }}$ values of a lime-stabilized Al-Ghat soil with fiber inclusion using FWP. The effect of dosage, length of the fiber, and curing period are considered in evaluating the $\mathrm{k}_{\text {sat }}$ values. Then, the values obtained from the study are compared with the values in the literature [13] to evaluate the effectiveness of FWP in the accurate measurement of $\mathrm{k}_{\text {sat }}$ values.

\section{Materials}

2.1. Soil

Locally available natural soil sourced from $\mathrm{Al}$ Ghat $\left(26^{\circ} 1^{\prime} 36^{\prime \prime} \mathrm{N}, 44^{\circ} 57^{\prime} 39^{\prime \prime} \mathrm{E}\right)$ town, Riyadh Province, Saudi Arabia, was selected for the present study. Disturbed samples were obtained from open test pits excavated to a depth of 1.5-3.0 m below the ground surface. The physical characterization of soil (carried out in accordance with relevant ASTM standards) seen from Table 1 reveals that the selected soil is a high plastic clay $(\mathrm{CH})$ as per the Unified Soil Classification System (USCS), and it is expansive in nature [13].

Table 1. Physical properties of studied soil.

\begin{tabular}{lc}
\hline \multicolumn{1}{c}{ Physical Property } & Value \\
\hline Liquid Limit $(\%)$ & 66 \\
Plastic Limit (\%) & 32 \\
Plasticity Index (\%) & 34 \\
Shrinkage Limit (\%) & 15 \\
Linear Shrinkage (\%) & 31 \\
$\%$ Finer No.200 sieve & 87 \\
Natural Moisture Content $(\%)$ & 3.2 \\
Maximum Dry Density $\left(\mathrm{kN} / \mathrm{m}^{3}\right)$ & 16.08 \\
Optimum Water Content $(\%)$ & 25 \\
Specific Gravity & 2.85 \\
Specific Surface Area $\left(\mathrm{BET} \mathrm{Method)}\left(\mathrm{m}^{2} / \mathrm{g}\right)\right.$ & 27.08 \\
USCS Classification & $\mathrm{CH}$ \\
Color & light brown \\
\hline
\end{tabular}




\subsection{Fiber}

Two types of fibers FM 300 and FC 500 supplied by Propex operating company (Chattanooga, TN, USA) were used for the present study. The physicochemical properties of two fibers are provided in Table 2. The length of fiber adopted for the experimental work is $6 \mathrm{~mm}$ and $12 \mathrm{~mm}$ for both FM and FC (Figure 1); the dosage of each fiber is fixed at $0.2 \%$ and $0.6 \%$ by weight of dry soil mass.

Table 2. Physicochemical properties of fibers.

\begin{tabular}{ccc}
\hline Property & Fiber Cast $\mathbf{5 0 0}$ (FC) & Fiber Mesh $\mathbf{3 0 0}$ (FM) \\
\hline Tensile Strength & $440 \mathrm{~N} / \mathrm{mm}^{2}$ & $330 \mathrm{~N} / \mathrm{mm}^{2}$ \\
Specific Gravity & 0.91 & 0.91 \\
Electrical Conductivity & Low & Low \\
Acid and Salt Resistance & High & High \\
Melt Point & $324^{\circ} \mathrm{F}\left(162^{\circ} \mathrm{C}\right)$ & $324^{\circ} \mathrm{F}\left(162^{\circ} \mathrm{C}\right)$ \\
Ignition Point & $1100^{\circ} \mathrm{F}\left(593^{\circ} \mathrm{C}\right)$ & $1100{ }^{\circ} \mathrm{F}\left(593^{\circ} \mathrm{C}\right)$ \\
Thermal Conductivity & Low & Low \\
Water Absorption & Nil & Nil \\
Alkali Resistance & Alkali Proof & Alkali Proof \\
Surface Texture & Relatively Smooth & Rough with Protrusions \\
Shape & Fibrillated & Monofilament \\
Aspect Ratio (L/D) & 42.8 and 120 & 193.5 and 387
\end{tabular}
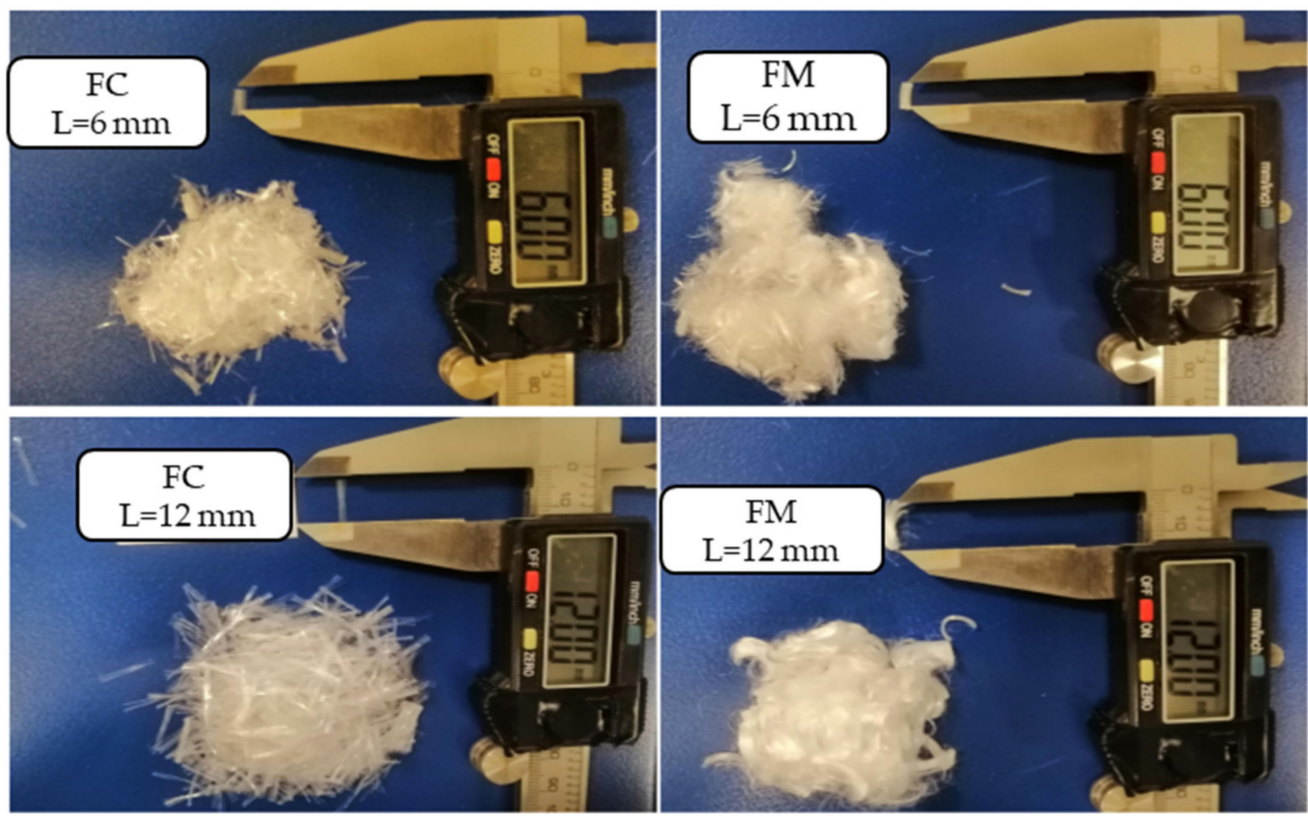

Figure 1. Fibers used in the study.

\subsection{Lime}

Locally available commercial-grade hydrated lime is used as a soil stabilizer. The percentage of lime was standardized at $6 \%$ for all tests by dry weight of the soil. This optimum quantity of lime was fixed relying on the soil-pH response upon the addition of lime [14,24].

\section{Experimental Program}

\subsection{Sample Preparation}

The expansive soil obtained from the field was air-dried, pulverized, and sieved using sieve No. 20. The soil fraction is mixed with optimum lime content (i.e., $6 \%$ of lime added to the soil by dry weight) and fiber (FC and FM) at selected dosages of $0.2 \%$ and $0.6 \%$. The 
lengths of fibers were kept at $6 \mathrm{~mm}$ and $12 \mathrm{~mm}$, resulting in 17 mix combinations in triplicates (including untreated soil) for the entire experimental work. A total of 51 specimens (including triplicates) were tested in FWP. Previous studies on the compaction properties of fiber-reinforced soil have revealed that the fiber inclusion had little or no effect on variations in maximum dry density (MDD) and optimum moisture content (OMC) of various mix proportions $[12,25,26]$. Based on this, all the specimens in the present study were molded at fixed MDD $\left(16.08 \mathrm{kN} / \mathrm{m}^{3}\right)$ and corresponding OMC (25\%). Soil, lime, and fibers at various proportions were mixed in dry condition; then, the target moisture content was added and mixed thoroughly to obtain a homogenous mixture. Statically compacted specimens of 70 $\mathrm{mm}$ diameter and $35 \mathrm{~mm}$ height were kept in a desiccator at a relative humidity $>95 \%$ and cured for a period of 7 and 28 days.

\subsection{Testing Procedure}

The evaluation of saturated hydraulic conductivity $\left(\mathrm{k}_{\mathrm{sat}}\right)$ was performed in accordance with ASTM D5084-Method A [27], using a flexible wall constant head permeameter. A schematic diagram of the test setup used in the present study is shown in Figure 2. At the end of each curing period, the prepared specimens were transferred to the cell. Porous stone and filter paper were kept on the top and bottom end of the specimen. A rubber membrane was used to confine the specimen; two O-rings placed at both ends provide a complete seal against any water leakage. The cell was filled with distilled water, and the drainage line at the bottom and top of the cell was flushed until no more air bubbles were observed inside the cell. The various stages involved in the testing phase are described below.

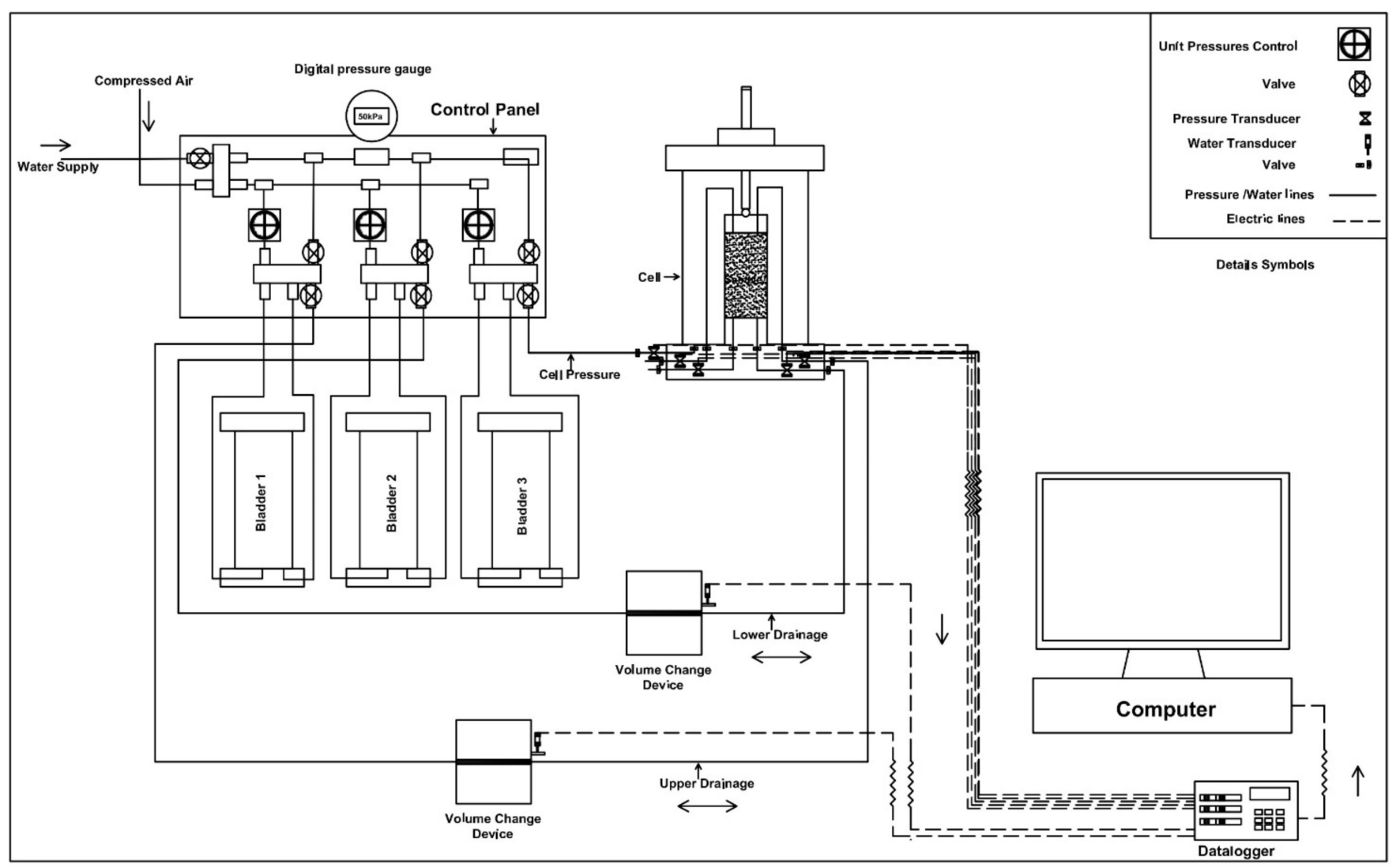

Figure 2. Schematic diagram of a flexible wall constant head permeameter.

\section{Back-Pressure Saturation:}

This stage involved a simultaneous increase of both the cell pressure $(\mathrm{CP})$ and the back pressure (BP) to reduce air bubbles or voids within the test sample. In this study, the effective confining pressure (defined as cell pressure minus back pressure, $\mathrm{CP}-\mathrm{BP}$ ) was kept at approximately $10 \mathrm{kPa}$ throughout the saturation process for all specimens. This effective 
confining pressure was selected to maintain sample stability without significantly affecting the stress history of the specimen. The (CP-BP) was maintained for one day. Specimen saturation was verified by measuring the $\mathrm{B}$ coefficient (defined as the difference in porewater pressure $(\Delta \mathrm{u})$, divided by the difference in pressure of the cells $(\triangle \mathrm{CP})$ of the porous material). A saturation check involved increasing the pressure of the cell on the specimen and monitoring the pore pressure response using a pore pressure transducer connected at the top and bottom of the specimen. The theoretical B value for a fully saturated specimen reaches 1 . However, in fluid flow experiments, specimens were considered saturated with the assurance of $B$ values $\geq 0.95$. If the $B$ value is less than 0.95 , the above procedure of increasing $\mathrm{CP}$ and $\mathrm{BP}$ and $\mathrm{B}$ value checking was repeated until the $\mathrm{B}$ value is $>0.95$.

II. Consolidation:

The specimens were consolidated under effective confining pressure (CP-BP) of 50, 100, 200 , and $400 \mathrm{kPa}$. Effective confining pressure was applied by increasing the cell pressure to the level necessary to develop the desired effective confining pressure while maintaining a constant back pressure. Drainage was allowed from the base of the specimen. The outflow volumes were recorded to confirm that primary consolidation has been completed before the initiation of the next stage.

III. Permeation:

This stage involved inducing flow-through test specimens by applying a differential pressure between the top and bottom of the specimens. The differential pressure was applied by reducing the top pressure and increasing the bottom pressure such that the difference was equal to the pressure head corresponding to the desired hydraulic gradient. To speed up the test, the hydraulic gradient was fixed at 30 [27]. The water inflow and outflow were continuously monitored until a steady-state condition was established as defined by the inflow rate being equal to the outflow rate.

\section{Results and Discussion}

\subsection{Effect of Confining Pressure}

Figures 3-6 show the variation in saturated hydraulic conductivity $\left(\mathrm{k}_{\mathrm{sat}}\right)$ values for lime-treated (at $6 \%$ ) expansive soil with fiber inclusion $(0.2 \%$ and $0.6 \%$ ) at various effective confining pressures at the end of each curing period.

In general, the $\mathrm{k}_{\mathrm{sat}}$ values reduced with an increase in confining pressure for all the tested specimens irrespective of fiber type, dosage, and curing period. A noticeable reduction in $\mathrm{k}_{\text {sat }}$ values is observed when the confining pressure is increased from 50 to $200 \mathrm{kPa}$. The flow of water through the compacted specimen depends on the availability and connectivity of inter and intra-aggregate flow channels, and the k value is directly related with inter-aggregate flow paths [28,29]. Increased confining pressure contributes to a significant reduction in inter-aggregate flow paths compared to intra-aggregate flow paths. Due to this, with the increase in pressure from 50 to $200 \mathrm{kPa}$, a significant reduction in inter-aggregate flow channels causes a decrease in $k_{\text {sat }}$ values. A further increment in confining pressure from 200 to $400 \mathrm{kPa}$ has less effect in reducing these flow paths and leads to a marginal reduction in $\mathrm{k}_{\text {sat }}$ values for all the tested specimens.

For any type of soil, the higher the confining pressure, the lower the $\mathrm{k}_{\text {sat }}$ values, irrespective of the permeating liquid [23]. Increased confinement causes a reduction in pore spaces and increases the unit weight, thus reducing the hydraulic conductivity [30]. Similar results were reported by de Brito Galvão et al. [31] and Shaker and Elkady [32].

The boundary condition adopted in the present study is highly correlated with the field conditions for the case of a subbase for pavements material in which the subbase material will be subjected to surcharge load coming on it. 


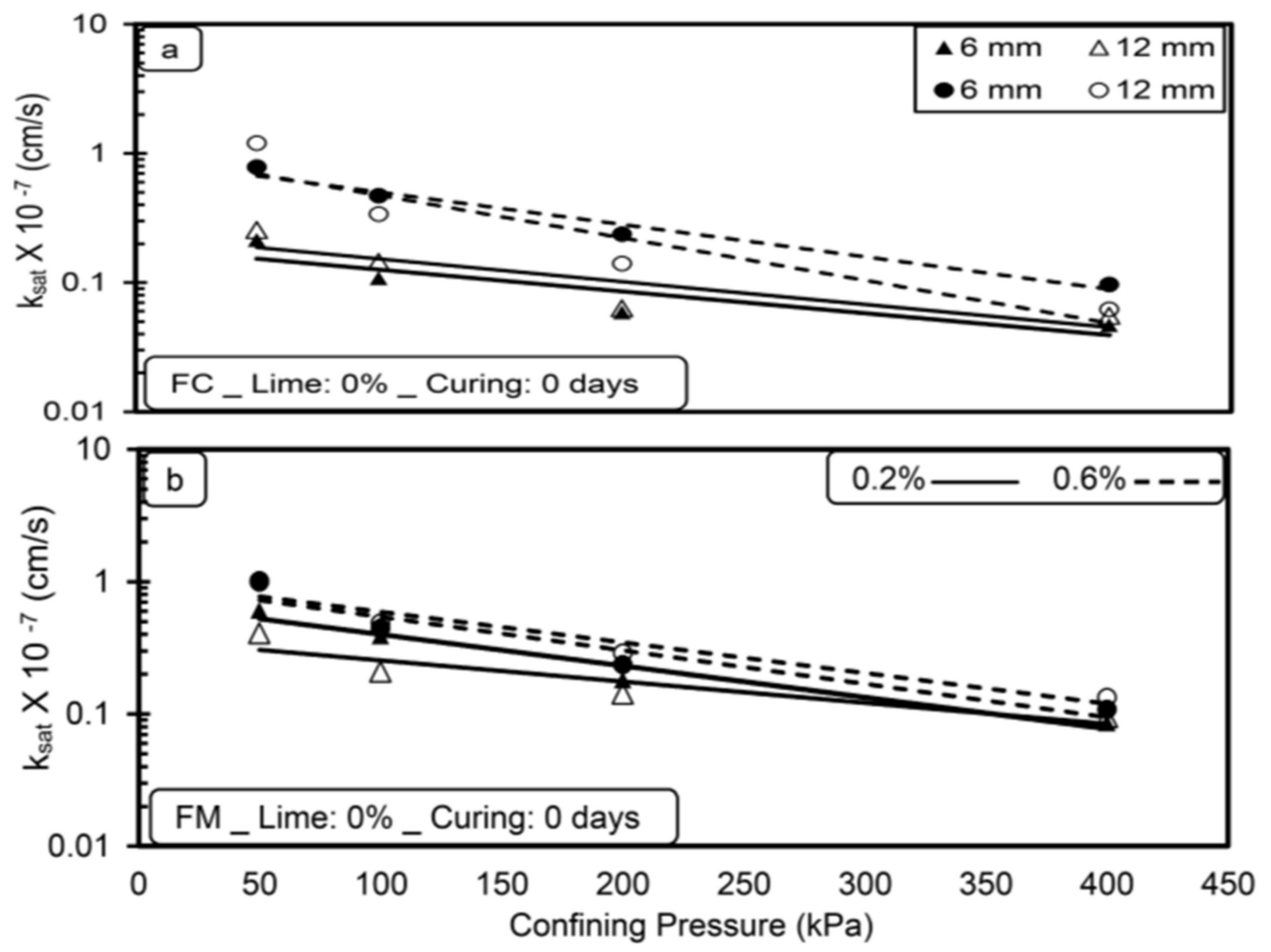

Figure 3. Variations in saturated hydraulic conductivity ( $k_{\text {sat }}$ ) with confining pressure (a) FC (b) FM without lime treatment (without curing).

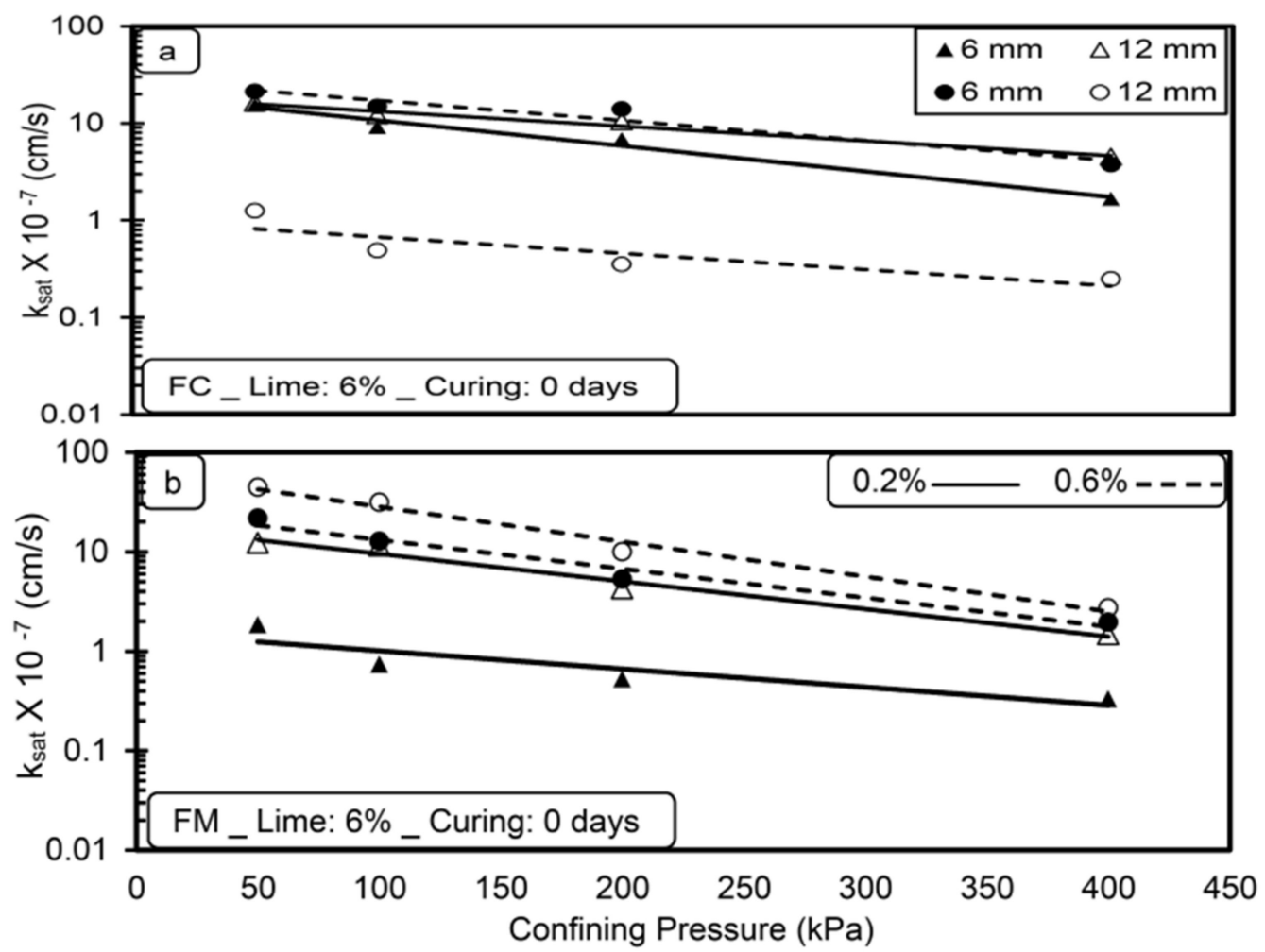

Figure 4. Variations in saturated hydraulic conductivity ( $\mathrm{k}_{\text {sat }}$ ) with confining pressure (a) FC (b) FM with lime treatment (without curing). 


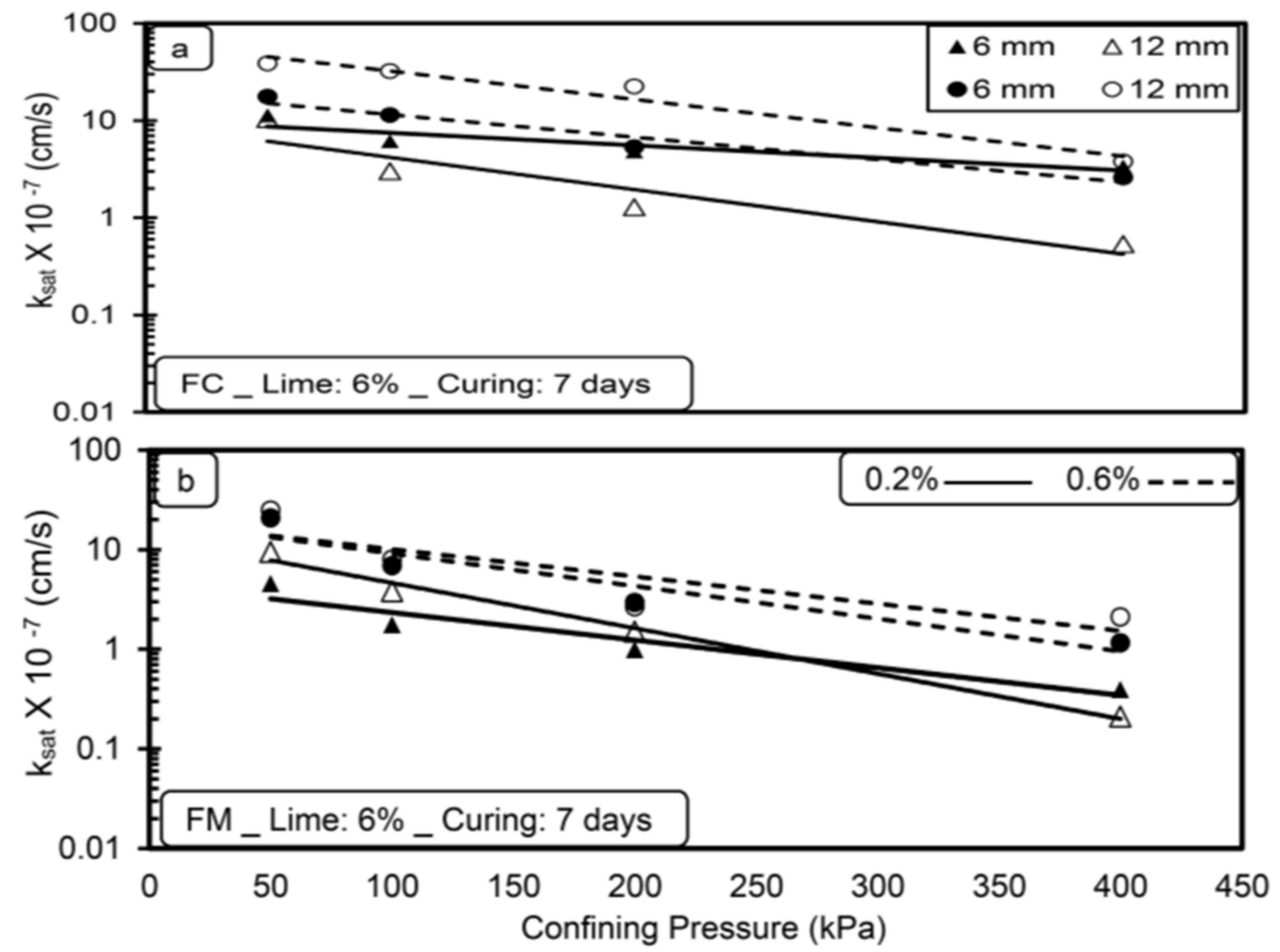

Figure 5. Variations in saturated hydraulic conductivity ( $\left.\mathrm{k}_{\mathrm{sat}}\right)$ with confining pressure (a) FC (b) FM with lime treatment (after 7-day curing period).

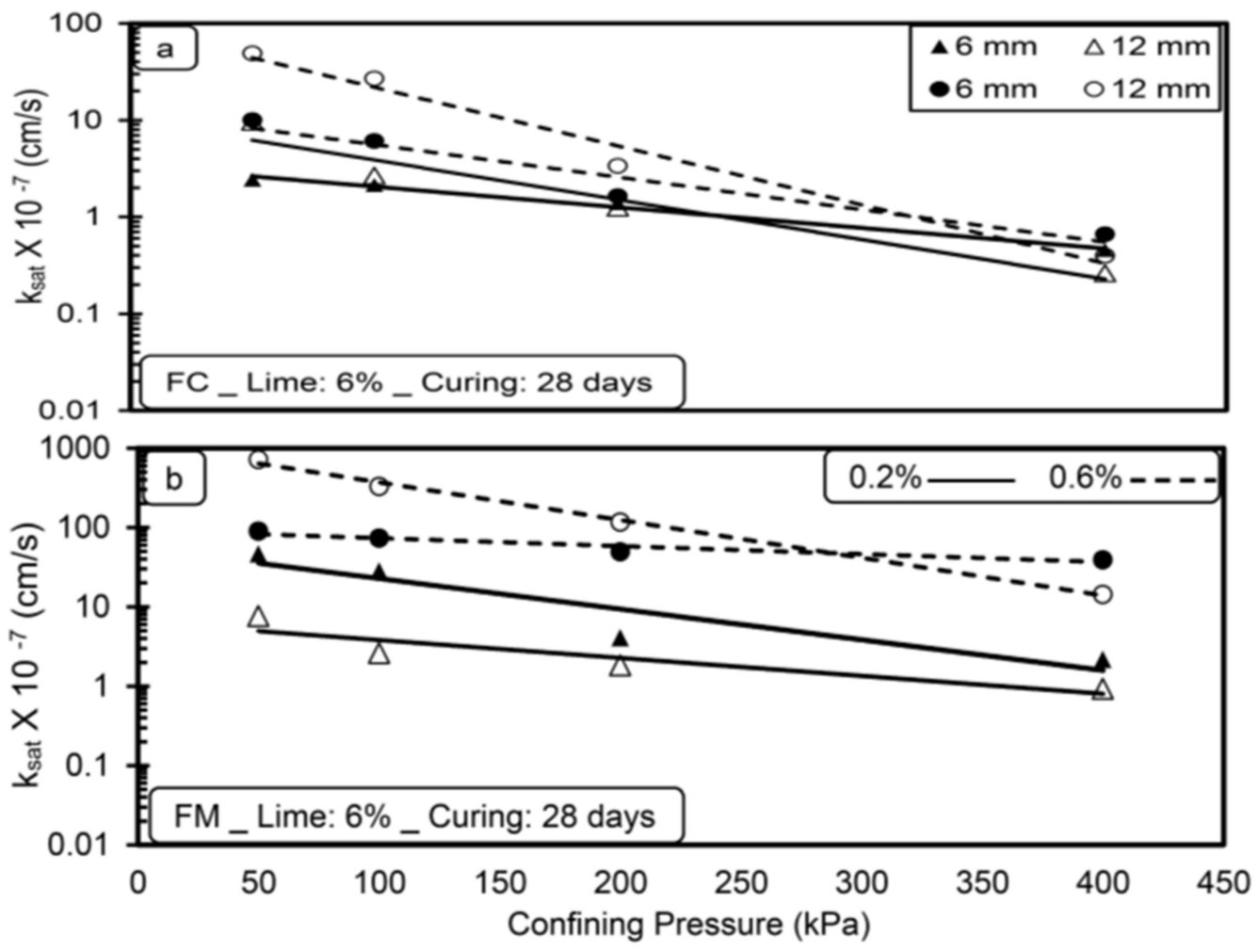

Figure 6. Variation of saturated hydraulic conductivity with confining pressure (a) FC (b) FM with lime treatment (after 28-day curing period). 


\subsection{Effect of Lime}

Figure 7 shows the variations in $\left(\mathrm{k}_{\text {sat }}\right)$ values with and without lime treatment for fiber-reinforced clay (FC and FM) without any curing. The addition of $6 \%$ lime causes an increase in $\mathrm{k}_{\mathrm{sat}}$ values in the order of $10^{-1} \mathrm{~cm} / \mathrm{s}$ for fiber-reinforced clay compared to that of an untreated case. The addition of lime leads to the aggregation of soil grains by $\mathrm{Ca}^{2+}$ ions, resulting in the formation of a flocculated structure $[33,34]$. The increased porosity of soil improves the connectivity of inter-aggregate pores and leads to an increase in $\mathrm{k}_{\text {sat }}$ values [31]. A similar trend is observed for all the tested specimens; however, the rate of increase in $\mathrm{k}_{\text {sat }}$ values is a function of fiber type, dosage, and length.

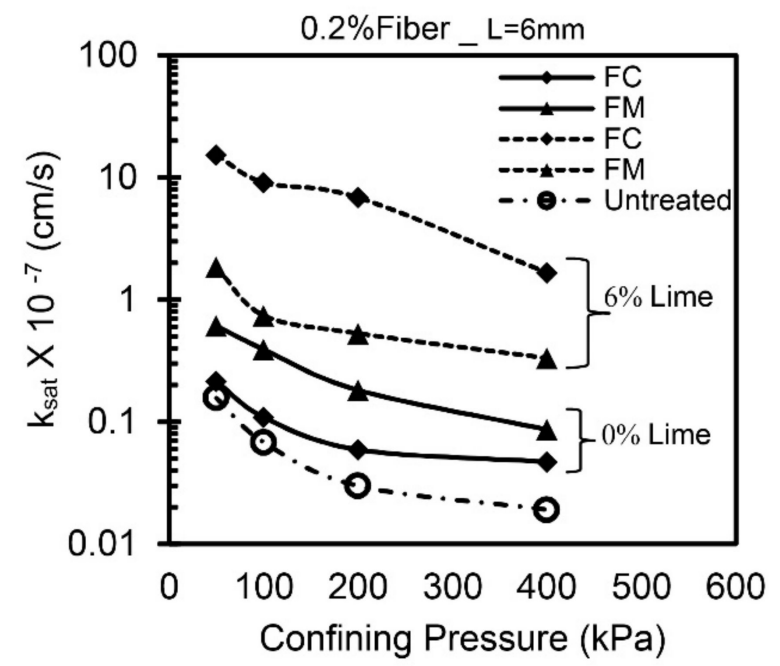

(a)

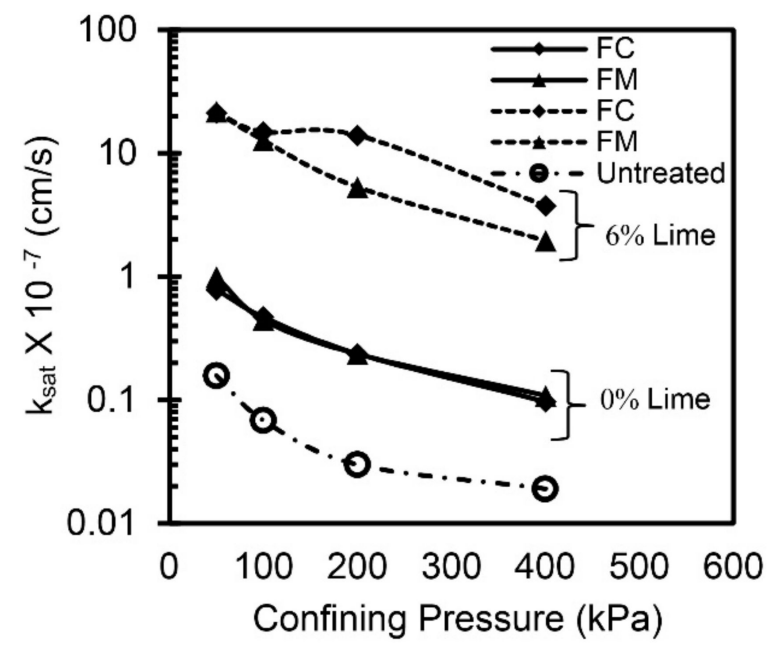

(c)

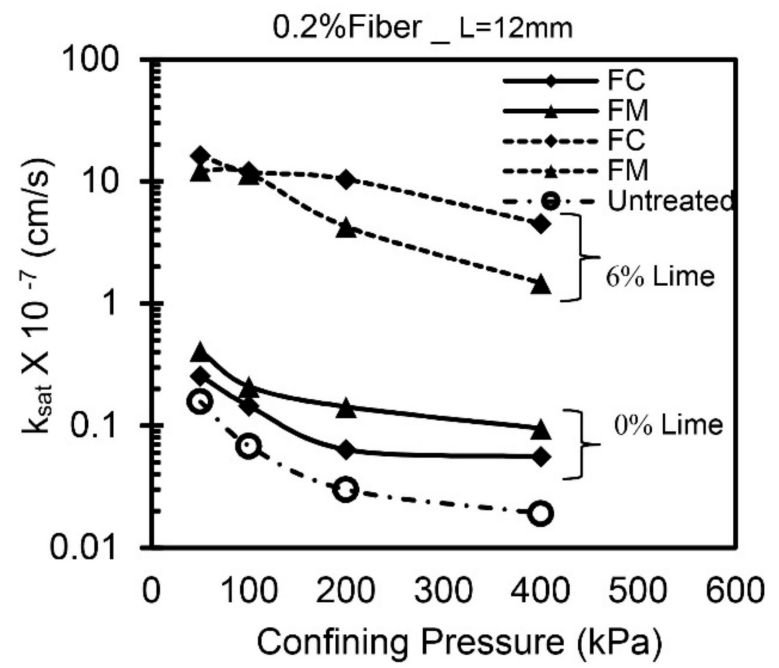

(b)

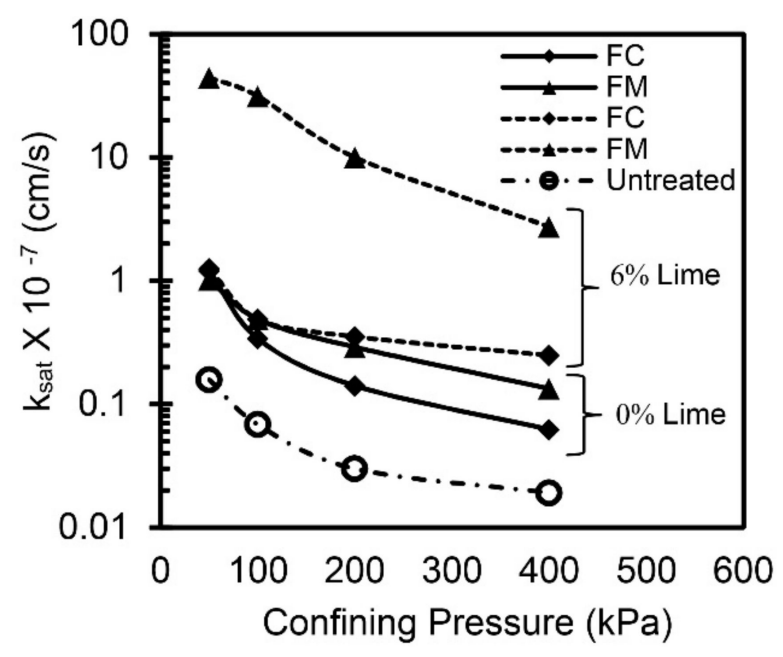

(d)

Figure 7. Variation of saturated hydraulic conductivity with lime content and confining pressure (a) $0.2 \%, 6 \mathrm{~mm}$; (b) $0.2 \%$, $12 \mathrm{~mm}$; (c) $0.6 \%, 6 \mathrm{~mm}$; (d) $0.6 \%, 12 \mathrm{~mm}$.

\subsection{Effect of Curing Time}

The effect of the curing period on the $\mathrm{k}_{\text {sat }}$ values of all samples with lime-treated expansive clay under different confining pressures is illustrated in Figure 8. Lime-treated soil reinforced with $0.2 \%$ FC (both $6 \mathrm{~mm}$ and $12 \mathrm{~mm}$ ) exhibited a reduction in $\mathrm{k}_{\text {sat }}$ values with an increase in curing period, as seen from Figure 8a. This is attributed to the fact that the cementitious compounds formed at a higher curing period fill the void spaces within the clay and the soil becomes less conductive [13]. At $0.6 \% \mathrm{FC}$, for $6 \mathrm{~mm}$ length 
of fibers, $\mathrm{k}_{\mathrm{sat}}$ values reduced marginally at a lower confining pressure (at $50 \mathrm{kPa}$ ), and a significant reduction is observed at higher confining pressure (at $400 \mathrm{kPa}$ ). Whereas, an increase in fiber length to $12 \mathrm{~mm}$ leads to an increase in $\mathrm{k}_{\text {sat }}$ values up to 7 days of curing and thereafter reduced at the end of a 28-day curing period (Figure $8 \mathrm{~b}$ ). This might be due to an increase in the length of fiber creating more drainage paths during the first 7 days of curing. However, after a 28-day curing period, this effect is dominated by the formation of cementitious compounds, which reduces the $\mathrm{k}_{\text {sat }}$ values with $12 \mathrm{~mm}$ fiber length.

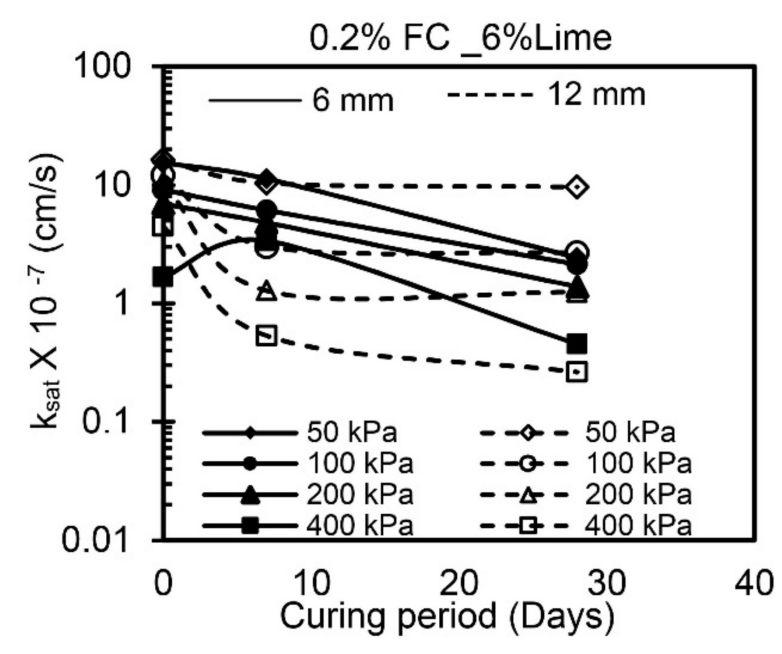

(a)

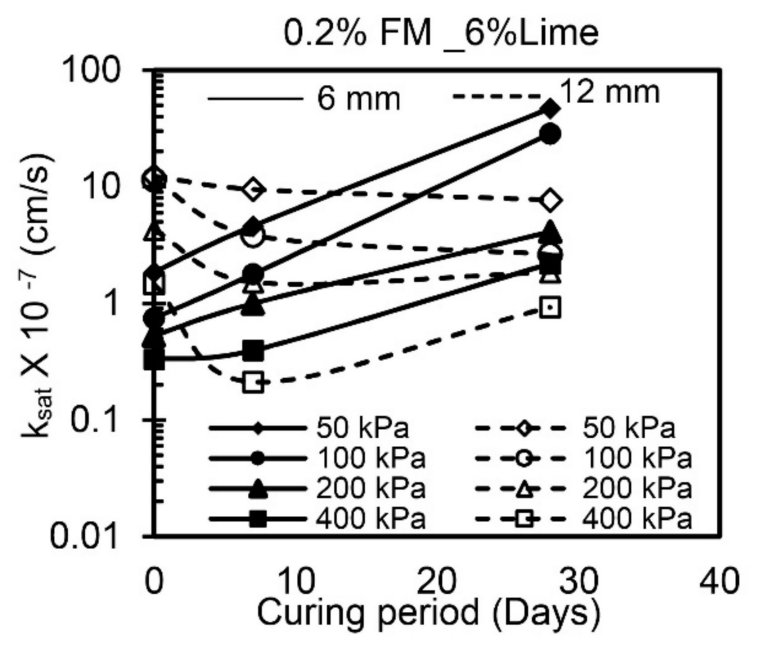

(c)

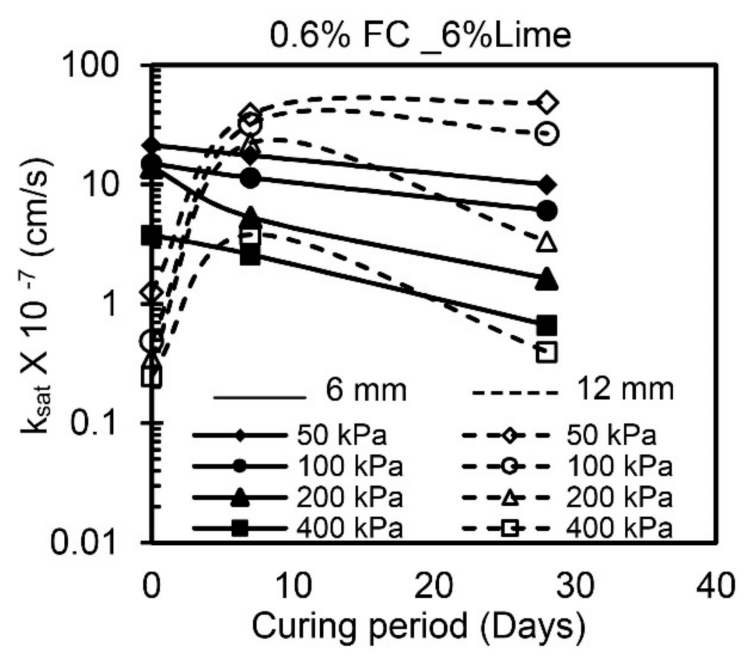

(b)

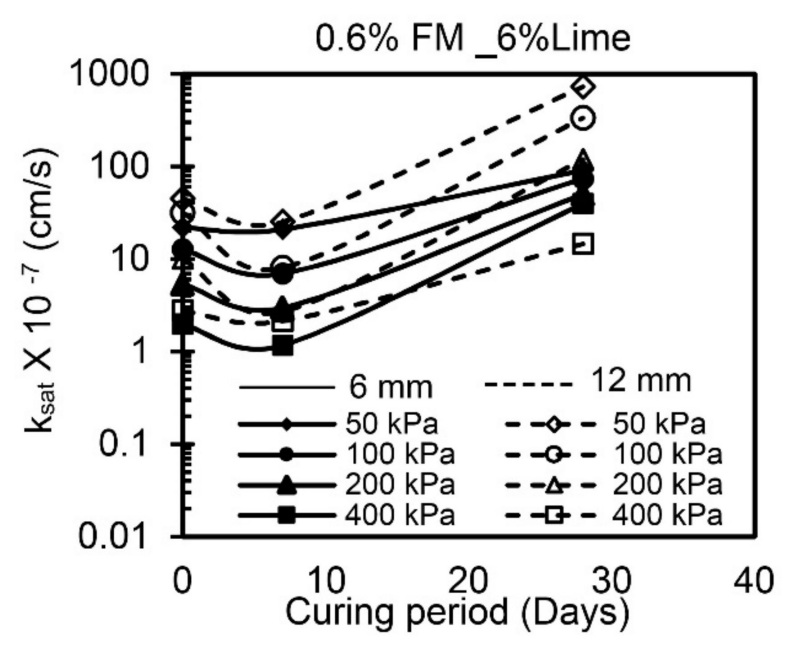

(d)

Figure 8. Variation of $k_{\text {sat }}$ values with curing period and confining pressure (a) FC_0.2\% (b) FC_0.6\% (c) FM_0.2\% (d) FM_0.6\%.

Figure $8 \mathrm{c}, \mathrm{d}$ depict the variations in $\mathrm{k}_{\text {sat }}$ values with FM addition at various curing periods. The $\mathrm{k}_{\mathrm{sat}}$ values increased at the end of the 28 -day curing period with a marginal reduction at 7 days compared with specimens without curing. Irrespective of the dosage and length of FM, the $\mathrm{k}_{\mathrm{sat}}$ values increased at all confining pressures.

\subsection{Effect of Fiber}

The results of permeability tests indicate that the $\mathrm{k}_{\mathrm{sat}}$ is a function of fiber type, dosage, and length (Figure 8). With an increase in dosage from 0.2 to $0.6 \%$, the $\mathrm{k}_{\text {sat }}$ values increased irrespective of the type of fiber for all specimens and are attributed to the randomly distributed fibers increasing the flow paths and causing free movement of the permeating liquid. In addition, an increase in fiber length from 6 to $12 \mathrm{~mm}$ results in an increase in 
$\mathrm{k}_{\text {sat }}$ values. However, this effect is not significant at higher curing periods. Relatively, the inclusion of FM results in increased $\mathrm{k}_{\text {sat }}$ values compared to the inclusion of FC, especially at $0.6 \%$ dosage. This behavior is attributed to the fact that the FM has a rough surface with protrusions (Table 2) compared to FC, which facilitates in creating more drainage paths and leading to an increase in the resultant $\mathrm{k}_{\text {sat }}$ values; whereas FC having a relatively smooth texture offers fewer drainage paths and leads to a reduction in $\mathrm{k}_{\text {sat }}$ values at higher curing periods. Similar observations were reported by Abdi et al. [10] and Maher and Ho [11].

\subsection{Comparison between Flexible Wall Permeameter and Rigid Wall Permeameter}

A comparison of the $\mathrm{k}_{\text {sat }}$ values obtained from the present study (using FWP at $50 \mathrm{kPa}$ ) and Moghal et al. [13] (using RWP) is presented in Figures 9-11 for the same materials under the same testing conditions. From Figures 9 and 10, the $\mathrm{k}_{\text {sat }}$ values obtained from FWP are lower than the $\mathrm{k}_{\mathrm{sat}}$ values obtained from RWP tests for the fiber-reinforced lime-treated soil specimens up to a 7-day curing period irrespective of fiber type. A notable variation in $\mathrm{k}_{\text {sat }}$ values (in the order of $10^{-1}$ ) is observed for specimens with $0.6 \%$ dosage and $12 \mathrm{~mm}$ length of fiber (FC and FM) compared to other combinations. Since complete control over the confining pressure and back saturation of a specimen prior to testing is possible in FWP, it leads to an accurate measurement of vertical and horizontal deformations and thus $\mathrm{k}_{\mathrm{sat}}$ values [21]. From the comparison, it is understood that FWP gives reliable results simulating the prevailing conditions in the field. For specimens cured for 28 days, the values of $\mathrm{k}_{\text {sat }}$ obtained using FWP are higher than those obtained from RWP (Figure 11). Experimental results on RWP have revealed that at higher curing periods ( 28 days), the leakage of liquid through the sidewalls of RWP due to loss of soil contact may significantly influence the $\mathrm{k}_{\text {sat }}$ values.

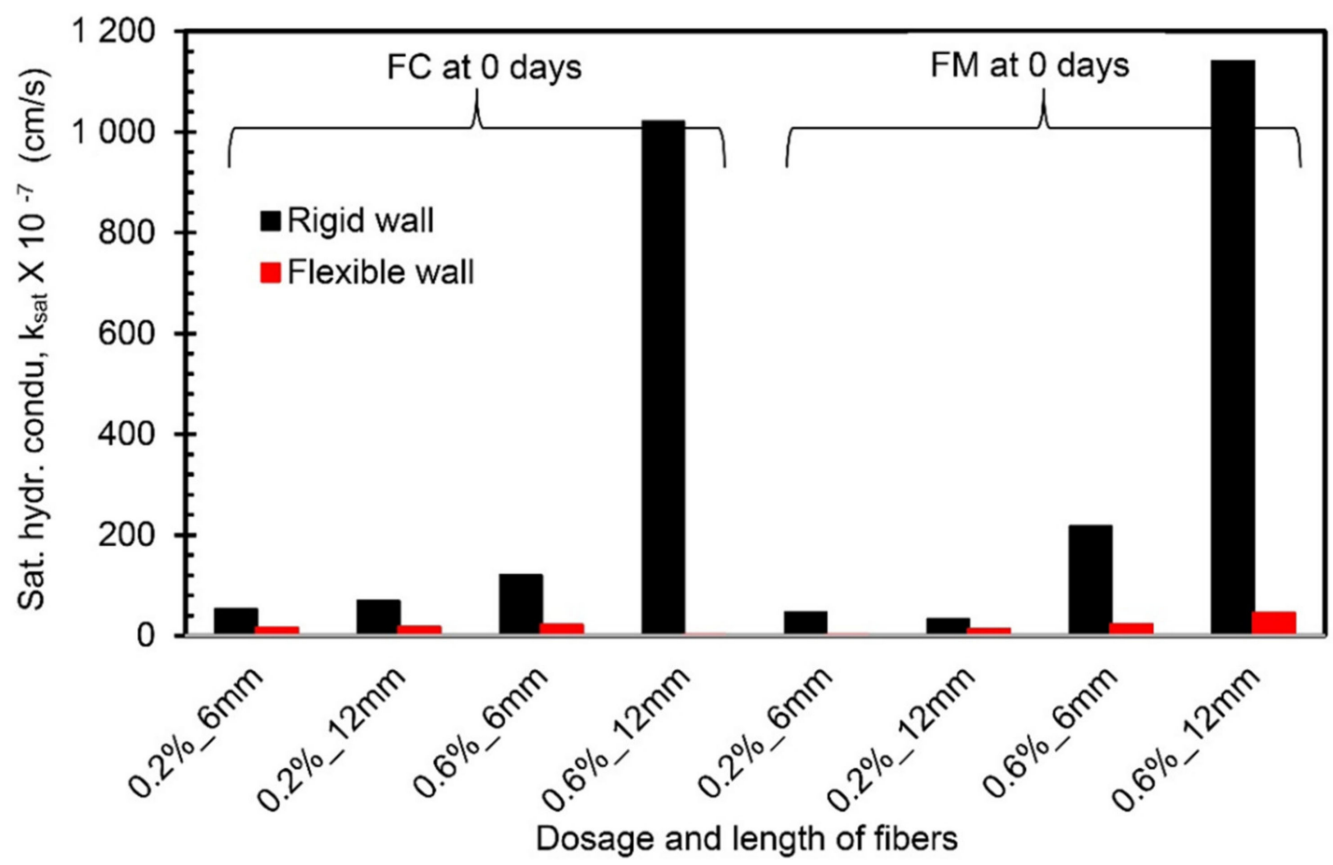

Figure 9. Comparison of hydraulic conductivity values from FWP and RWP (0-day curing period). 


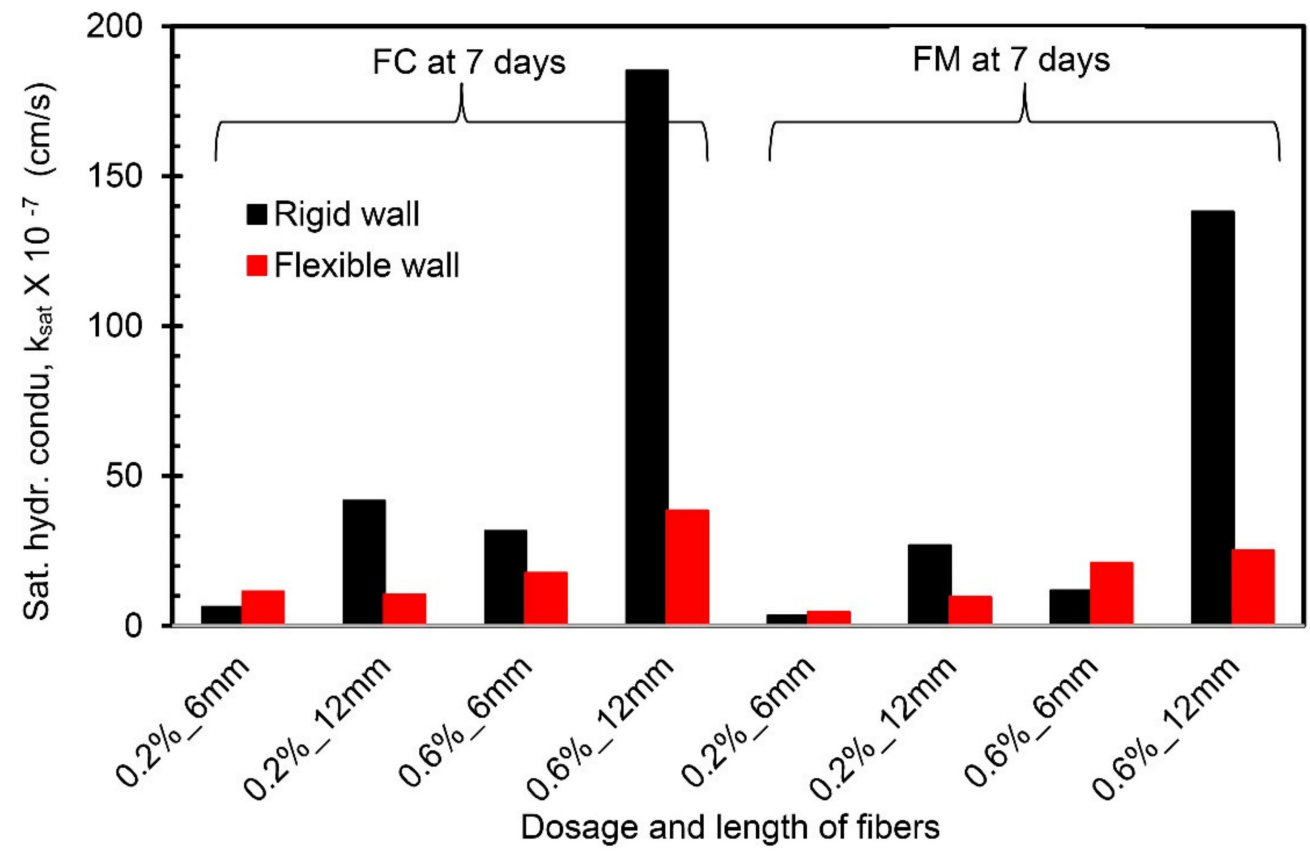

Figure 10. Comparison of hydraulic conductivity values from FWP and RWP (7-day curing period).

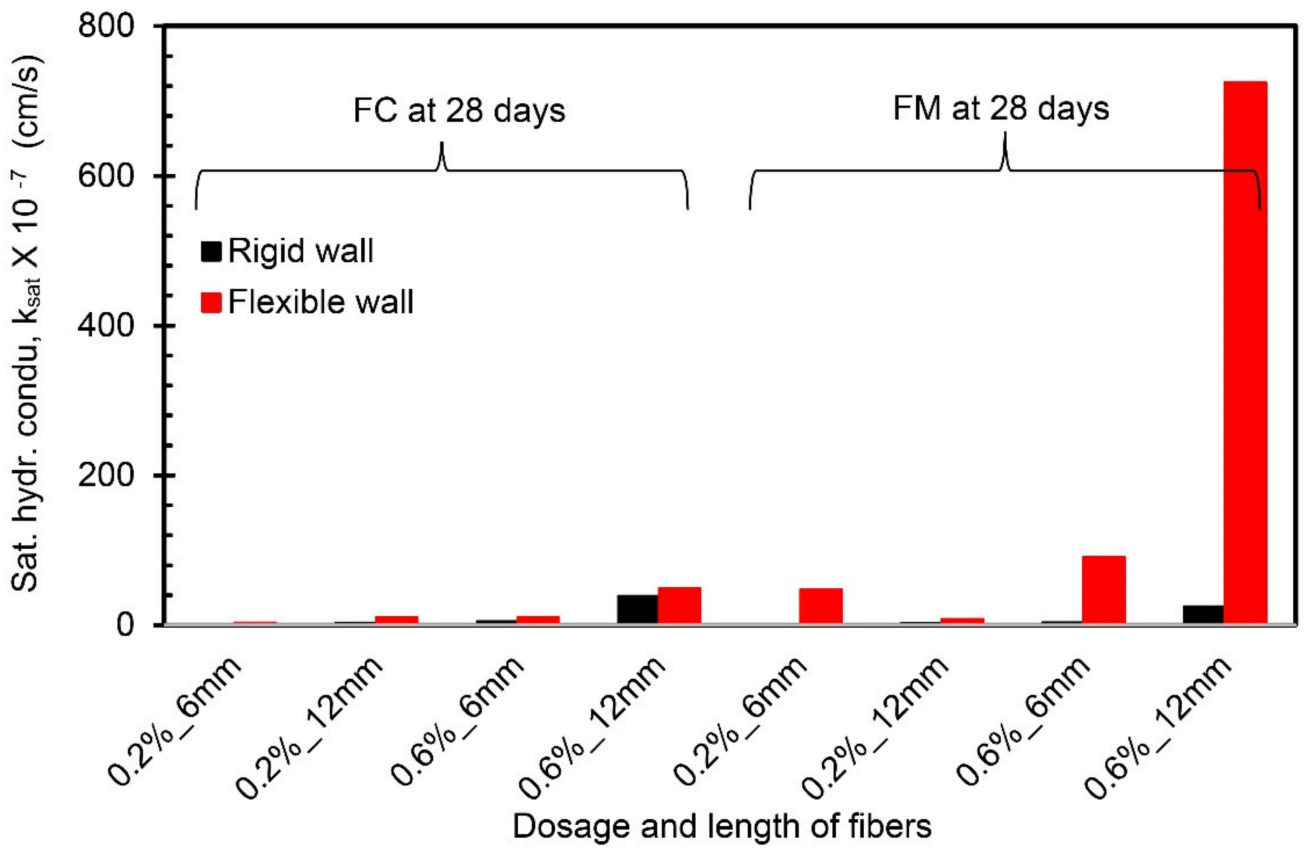

Figure 11. Comparison of hydraulic conductivity values from FWP and RWP (28-day curing period).

\section{Conclusions}

The present study evaluated the effect of fiber inclusion (FC and FM) on saturated hydraulic conductivity $\left(\mathrm{k}_{\mathrm{sat}}\right)$ of lime-treated expansive clay. The constant head method using FWP at various confining pressures is adopted for experimental work. The $\mathrm{k}_{\text {sat }}$ values were evaluated at various dosages $(0.2 \%$ and $0.6 \%)$, fiber lengths (6 and $12 \mathrm{~mm})$, and curing periods (7 and 28 days). The following conclusions are drawn:

- The addition of lime significantly increased the $\mathrm{k}_{\text {sat }}$ values compared to untreated specimens.

- At lower confining pressures (50 to $200 \mathrm{kPa}$ ), the reduction in $\mathrm{k}_{\text {sat }}$ values is attributed to a decrease in inter-aggregate flow paths. This effect is not significant at higher confining pressure $(400 \mathrm{kPa})$. 
- An increase in the dosage and lengths of fiber leads to an increase in $\mathrm{k}_{\mathrm{sat}}$ values irrespective of the fiber type.

- For FC at $0.2 \%$, the $\mathrm{k}_{\text {sat }}$ values reduced at the end of the 28-day curing period irrespective of the length of fiber used. At $0.6 \%$ dosage, the values marginally increased for the $12 \mathrm{~mm}$ fiber length due to increased drainage paths.

- For FM, the $\mathrm{k}_{\text {sat }}$ values increased at the end of 28 days irrespective of dosage and fiber length at all confining pressures.

- $\quad \mathrm{k}_{\text {sat }}$ values are directly dependent on the nature and type of fiber used, of which FM fibers with extended protrusions enable higher friction levels. For FC fibers, increased fiber dosage from 0.2 to $0.6 \%$ has caused an increase in $\mathrm{k}_{\text {sat }}$ values by $9.5 \%$ and $94.3 \%$ for the 6 and $12 \mathrm{~mm}$ lengths, respectively, at all confining pressures. In contrast, for a similar change in fiber amount for FM fibers, the $k_{\text {sat }}$ values for samples mixed with $6 \mathrm{~mm}$ fiber increased by 12 and $99.2 \%$ for 6 and $12 \mathrm{~mm}$ lengths, respectively for all confining pressures.

Author Contributions: A.A.S.: Methodology, Formal Analysis, Investigation, Data Curation, Writing Original Draft; M.A.A.-S.: Supervision, Funding Acquisition, Review and Editing; A.A.B.M.: Conceptualization, Writing Original Draft, Review and Editing, Moral Support; K.V.V.: Writing Original Draft and Final Version, Visualization. All authors have read and agreed to the published version of the manuscript.

Funding: This work is funded by Deanship of Scientific Research, King Saud University through Vice Deanship of Scientific Research Chairs.

Institutional Review Board Statement: Not applicable.

Informed Consent Statement: Not applicable.

Data Availability Statement: The content presented here was sourced from existing published literature, hence, this clause is not applicable.

Acknowledgments: The authors extend their appreciation to the Deanship of Scientific Research, King Saud University for funding this study through Vice Deanship of Scientific Research Chairs.

Conflicts of Interest: The authors declare no conflict of interest.

\begin{tabular}{|c|c|}
\hline \multicolumn{2}{|c|}{ Abbreviations } \\
\hline \multicolumn{2}{|c|}{ The following symbols are used in this paper: } \\
\hline $\mathrm{B}$ & Coefficient of Saturation \\
\hline $\mathrm{BP}$ & Back Pressure \\
\hline $\mathrm{CP}$ & Cell Pressure \\
\hline FC & Fiber Cast \\
\hline FM & Fiber Mesh \\
\hline FWP & Flexible Wall Permeameter \\
\hline $\mathrm{k}_{\text {sat }}$ & Saturated hydraulic conductivity \\
\hline RWP & Rigid Wall Permeameter \\
\hline$\triangle \mathrm{CP}$ & The difference in cell pressure \\
\hline$\Delta \mathrm{u}$ & The difference in pore-water pressure \\
\hline
\end{tabular}

\section{References}

1. Puppala, A.J.; Musenda, C. Effects of fiber reinforcement on strength and volume change in expansive soils. Transp. Res. Rec. 2000, C, 134-140. [CrossRef]

2. Yetimoglu, T.; Salbas, O. A study on shear strength of sands reinforced with randomly distributed discrete fibers. Geotext. Geomembr. 2003, 21, 103-110. [CrossRef]

3. Moghal, A.A.B.; Bhaskar, C.S.C.; Basha, B.M. Effect of fibre reinforcement on CBR behaviour of lime-blended expansive soils: Reliability approach. Road Mater. Pavement Des. 2017, 19, 690-709. [CrossRef]

4. Moghal, A.A.B.; Lateef, M.A.; Mohammed, S.A.S.; Ahmad, M.; Usman, A.R.A.; Almajed, A. Heavy Metal Immobilization Studies and Enhancement in Geotechnical Properties of Cohesive Soils by EICP Technique. Appl. Sci. 2020, 10, 7568. [CrossRef] 
5. Almajed, A.; Lateef, M.A.; Moghal, A.A.B.; Lemboye, K.K. State-of-the-Art Review of the Applicability and Challenges of Microbial-Induced Calcite Precipitation (MICP) and Enzyme-Induced Calcite Precipitation (EICP) Techniques for Geotechnical and Geoenvironmental Applications. Crystals 2021, 11, 370. [CrossRef]

6. Moghal, A.A.B.; Vydehi, K.V. State-of-the-art review on efficacy of xanthan gum and guar gum inclusion on the engineering behavior of soils. Innov. Infrastruct. Solut. 2021, 6, 1-14. [CrossRef]

7. Khattak, M.J.; Alrashidi, M. Durability and mechanistic characteristics of fiber reinforced soil-cement mixtures. Int. J. Pavement Eng. 2006, 7, 53-62. [CrossRef]

8. Viswanadham, B.V.S.; Phanikumar, B.R.; Mukherjee, R.V. Swelling behaviour of a geofiber-reinforced expansive soil. Geotext. Geomembr. 2009, 27, 73-76. [CrossRef]

9. Moghal, A.A.B.; Bhaskar, C.S.C.; Basha, B.M.; Al-Mahbashi, A.M. Effect of polypropylene fibre reinforcement on the consolidation, swell and shrinkage behaviour of lime-blended expansive soil. Int. J. Geotech. Eng. 2018, 12, 462-471. [CrossRef]

10. Abdi, M.R.; Parsapajouh, A.; Arjomand, M.A. Effects of Random Fiber Inclusion on Consolidation, Hydraulic Conductivity, Swelling, Shrinkage Limit and Desiccation Cracking of Clays. Int. J. Civ. Eng. 2008, 6, 284-292.

11. Maher, M.; HO, Y. Mechanical properties of kaolinite/fiber soil composite. J. Geotech. Eng. ASCE 1994, 120, 1381-1393. [CrossRef]

12. Miller, C.J.; Rifai, S. Fiber Reinforcement for Waste Containment Soil Liners. J. Environ. Eng. 2004, 130, 891-895. [CrossRef]

13. Moghal, A.A.B.; Basha, B.M.; Ashfaq, M. Probabilistic Study on the Geotechnical Behavior of Fiber Reinforced Soil; Springer: Singapore, 2019; ISBN 9789811358715.

14. Moghal, A.A.B.; Basha, B.M.; Chittoori, B.; Al-Shamrani, M.A. Effect of fiber reinforcement on the hydraulic conductivity behavior of lime-treated expansive soil-Reliability-based optimization perspective. ASCE Geotech Spec. Publ. No 2016, 263, 25-34. [CrossRef]

15. Almajed, A.; Dinesh, S.; Moghal, A.A.B. Response Surface Method Analysis of Chemically Stabilized Fiber-Reinforced Soil. Materials 2021, 14, 1535. [CrossRef] [PubMed]

16. Shaker, A.A.; Elkady, T.Y. Investigation of the hydraulic efficiency of sand-natural expansive clay mixtures. Int. J. Geomate 2016, 11, 2410-2415. [CrossRef]

17. Nalbantoglu, Z.; Tuncer, E.R. Compressibility and hydraulic conductivity of a chemically treated expansive clay. Can. Geotech. J. 2001, 38, 154-160. [CrossRef]

18. Locat, J.; Trembaly, H.; Leroueil, S. Mechanical and hydraulic behaviour of a soft inorganic clay treated with lime. Can. Geotech. J. 1996, 33, 654-669. [CrossRef]

19. Metelková, Z.; Bohác, J.; Sedlárová, I.; Prikryl, R. Changes of pore size and of hydraulic conductivity by adding lime in compacting clay liners. In Geotechnical Engineering: New Horizons, Proceedings of the 21st European Young Geotechnical Engineers Conference Rotterdam 2011, Amsterdam, The Netherlands, 4-7 September 2011; IOS Press: Amsterdam, The Netherlands, 2011; Volume 2011, pp. 93-98. [CrossRef]

20. Tran, T.D.; Cui, Y.J.; Tang, A.M.; Audiguier, M.; Cojean, R. Effects of lime treatment on the microstructure and hydraulic conductivity of Héricourt clay. J. Rock Mech Geotech. 2014, 6, 399-404. [CrossRef]

21. Daniel, D.E.; Anderson, D.C.; Boynton, S.S. Fixed-wall versus flexible-wall permeameters. In Hydraulic Barriers in Soil and Rock; ASTM STP, 874; Johnson, A.I., Frobel, R.K., Cavalli, N.J., Pettersson, C.B., Eds.; ASTM: West Conshohoken, PA, USA, 1985; pp. 107-126. [CrossRef]

22. Kang, J.; Shackelford, C.D. Clay membrane testing using a flexible-wall cell under closed-system boundary conditions. Appl. Clay Sci. 2009, 44, 43-58. [CrossRef]

23. Dafalla, M.; Shaker, A.A.; Elkady, T.; Al-Shamrani, M.; Dhowian, A. Effects of confining pressure and effective stress on hydraulic conductivity of sand-clay mixtures. Arab. J. Geosci. 2015, 8, 9993-10001. [CrossRef]

24. Eades, J.L.; Grim, R.E. A Quick Test to Determine Lime Requirements For Lime Stabilization. Highw. Res. Rec. 1966, 5, 61-72.

25. Nataraj, M.S.; McManis, K.L. Strength and deformation properties of soils reinforced with fibrillated fibers. Geosynth. Int. 1997, 4, 65-79. [CrossRef]

26. Soganci, A.S. The Effect of Polypropylene Fiber in the Stabilization of Expansive Soils. Int. J. Environ. Chem. Ecol. Geophys. Eng. 2015, 9, 956-959. [CrossRef]

27. ASTM International. ASTM D5084-03: Standard Test Methods for Measurement of Hydraulic Conductivity of Saturated Porous Materials Using a Flexible Wall Permeameter; ASTM International: West Conshohocken, PA, USA, 2003.

28. Olsen, H.W. Hydraulic flow through saturated clays. In Proceedings of the 9th National Conference on Clays and Clay Minerals, Lafayette, IN, USA, 5-8 October 1960; pp. 131-161. [CrossRef]

29. Scholes, O.N.; Clayton, S.A.; Hoadley, A.F.A.; Tiu, C. Permeability anisotropy due to consolidation of compressible porous media. Transp Porous Media. 2007, 68, 365-387. [CrossRef]

30. Elkady, T.Y.; Shaker, A.; Al-Shamrani, M. Hydraulic Conductivity of Compacted Lime-Treated Expansive Soils. In Proceedings of the Fourth Geo-China International Conference, Geo-China 2016, Shandong, China, 25-27 July 2016; ASCE: Shandong, China, 2016; pp. 52-59. [CrossRef]

31. de Brito Galvão, T.C.; Elsharief, A.; Simões, G.F. Effects of Lime on Permeability and Compressibility of Two Tropical Residual Soils. J. Environ. Eng. 2004, 130, 881-885. [CrossRef] 
32. Shaker, A.A.; Elkady, T.Y. Hydraulic performance of sand-clay mixtures: Soil fabric perspective. Géotechnique Lett. 2015, 5, 198-204. [CrossRef]

33. Bell, F.G. Lime stabilization of clay minerals and soils. Eng. Geol. 1996, 42, 223-237. [CrossRef]

34. Moghal, A.A.B.; Rehman, A.U.; Vydehi, K.V.; Umer, U. Sustainable Perspective of Low-Lime Stabilized Fly Ashes for Geotechnical Applications: PROMETHEE-Based Optimization Approach. Sustainability 2020, 12, 6649. [CrossRef] 